University of Miami Law School University of Miami School of Law Institutional Repository

1995

\title{
Environmental Protection in Archipelagic Waters and International Straits-The Role of the International Maritime Organisation
}

Bernard H. Oxman

University of Miami School of Law, bhoxman@law.miami.edu

Follow this and additional works at: https://repository.law.miami.edu/fac_articles

Part of the Law of the Sea Commons

\section{Recommended Citation}

Bernard H. Oxman, Environmental Protection in Archipelagic Waters and International Straits-The Role of the International Maritime Organisation, 10 Int'l J. Marine \& Coastal L. 467 (1995).

This Article is brought to you for free and open access by the Faculty and Deans at University of Miami School of Law Institutional Repository. It has been accepted for inclusion in Articles by an authorized administrator of University of Miami School of Law Institutional Repository. For more information, please contact library@law.miami.edu. 


\title{
Environmental Protection in Archipelagic Waters and International Straits-The Role of the International Maritime Organisation
}

\author{
Bernard H. Oxman \\ Professor of Law. University of Miami, USA
}

The classic Grotian option for regulating activities at sea is to rely on regulation by the state of nationality - typically the flag state of a ship-without regard to location. Another option is to rely on regulation by the coastal state in a given geographic area off its coast, without regard to the nationality of those regulated.

For centuries, a major function of the law of the sea was to mediate between these two options, determining where, when and how each of them applied. The law of treaties, not the law of the sea as such, often provided the basis for imposing detailed restraints on how either coastal states or flag states exercised their regulatory powers. One of the most important general rules of the law of treaties is that treaties bind only their parties.

To the two classic options, the UN Convention on the Law of the Sea adds a third option for regulating activities at sea: reliance on international organizations to formulate norms that states are obliged to respect and enforce. This development is of course most obvious with respect to deep seabed mining, where the Convention creates the organization. But this development may be even more significant with respect to navigation safety and protection of the marine environment, where the Convention relies on international organizations created by other treaties. The Convention generally does not name these organizations, but rather uses a generic reference to the competent international organization. For many if not most purposes the competent international organization is generally regarded to be the International Maritime Organisation (IMO). We should not lose sight of the fact,

This paper was originally given at the 29 th Annual Conference of the Law of the Sea Institute in Denpasar, Bali, 19-22 June, 1995.

THE INTERNATIONAL JOURNAL OF MARINE AND COASTAL LAW, Vol 10, No 4 (C) Kluwer Law International, 1995 
however, that the Convention also contemplates that IMO's work will be supplemented by regional efforts on matters appropriate for regional action, whether through the regional seas programme of the UN Environment Programme or other regional organizations and arrangements such as the ambitious efforts of ASEAN.

The Law of the Sea Convention also relies on international judicial and arbitral tribunals as part of its structural allocation of regulatory powers. Both IMO and these tribunals are accorded important roles in this regard. Without them, including the vessel-release competence of the new International Tribunal for the Law of the Sea, the allocation of jurisdiction between flag states and coastal states might have looked very different in the Convention. Indeed, there might have been no generally acceptable basis for agreement at all.

\section{The IMO's Roles}

The IMO has three different roles under the Law of the Sea Convention. One role is as a forum for international co-operation, sharing of information, and negotiation of international standards (forum role). A second role relates to the legal effect under the Convention of rules promulgated by or through the IMO or in IMO-related treaties (standard-setting role). A third role is to review and, if it agrees, approve specific regulatory proposals of individual states (approval role).

IMO's forum and standard-setting roles are relevant to two different types of provisions. One type deals with the safety and environmental duties of a state with respect to activities subject to its jurisdiction and control, including those of ships of its nationality. Another type deals with the regulatory powers of riparian states over navigation by foreign ships. IMO's approval role is relevant only to the second type of provision.

The main purposes for requiring adherence to IMO standards by a flag state with respect to regulation of ships of its nationality, or by a coastal state with respect to sea-bed activities and offshore installations subject to its jurisdiction, are to promote safety and to protect the marine environment. The main purposes for requiring adherence to IMO standards, or requiring IMO approval of regulations, by a coastal state with respect to its regulatory powers over navigation by foreign ships, are to protect navigational rights and freedoms and to ensure compatibility with general safety and environmental norms and practices.

\section{General Environmental Obligations}

IMO's forum role arises explicitly with the greatest frequency under Part XII of the Law of the Sea Convention, which deals with protection and preservation of the marine environment. The IMO has, or can plausibly exercise, a vast array of

1 See e.g. Law of the Sea Convention, Articles 197-206. Footnote references are to this Convention articles unless indicated to the contrary. 
forum roles under the opening sections of Part XII,' as well as in connection with specific references to particular sources of pollution elsewhere in Part XII and other parts of the Convention.

I also believe that IMO's standard-setting role is relevant to the general environmental norms articulated by the first section of Part XII. In considering how to apply the over-arching obligation of states to protect and preserve the marine environment, ${ }^{2}$ or to determine what anti-pollution measures are necessary, ${ }^{3}$ lawyers and judges are likely to consult the standards emanating from international forums, including the IMO.

Of course, where navigation and certain other activities are concerned, other provisions of Part XII are explicit with respect to the standard-setting role of IMO. But lawyers and judges may well look to the opening general provisions of Part XII in order to inform their interpretation of more specific provisions and in order to fill gaps.

\section{Specific Activities other than Navigation}

Most discussions of straits and archipelagic waters concentrate on their navigation regimes as such. But IMO's roles under the Convention are not limited to regulation of navigation. IMO is accorded both a forum role and a standard-setting role with respect to ocean dumping, sea-bed activities subject to coastal state jurisdiction, and offshore installations subject to coastal state jurisdiction.

\section{Ocean Dumping}

Article 210 requires that national laws and regulations on ocean dumping, including those of the flag state and the coastal state, be "no less effective than the global rules and standards". This principle applies to all of the marine environment, including straits and archipelagic waters. ${ }^{4}$ The London Ocean Dumping Convention, negotiated and updated under IMO auspices, is the obvious place to look for the global rules and standards.

\section{Sea-bed Activities and Offshore Installations}

In light of its work in the field, including the International Convention for the Prevention of Pollution from Ships, 1973, incorporated in and modified by the 1978 Protocol (the MARPOL Convention), and its annexes, which include requirements for certain offshore installations, IMO is a competent forum for

\footnotetext{
Article 192.

Article 194.

Article 210(6). It might be noted that Article 210, para. 5, unlike the other paragraphs of Article 210 , refers only to the territorial sea, exclusive economic zone, and continental shelf. Paragraph 5 does not deal with the duty to comply with global rules and standards, but with the coastal state right to permit, regulate and control dumping. By virtue of its sovereignty, the coastal state also has that right in archipelagic waters and internal waters. See Articles 2(1), 49.
} 
negotiating and reviewing global international rules and recommendations for the prevention and control of pollution from sea-bed activities and offshore installations subject to coastal state jurisdiction. ${ }^{5}$ Coastal state laws and regulations must be "no less effective than international rules, standards and recommended practices and procedures" for prevention and control of such pollution. ${ }^{6}$ This principle applies to all sea-bed activities subject to coastal state jurisdiction, including those in straits and archipelagic waters. ${ }^{7}$

However, because of a cross-reference to Articles 60 and 80 , which deal with offshore installations and structures and related safety zones in the exclusive economic zone (EEZ) and on the continental shelf, this. "no less effective" principle applies expressly to offshore installations only in the EEZ or on the continental shelf. ${ }^{8}$ The reason for this had nothing to do with the duty to protect the environment, but rather with concern that the precise scope of coastal state jurisdiction over offshore installations and structures under Articles 60 and 80, a sensitive and closely negotiated matter affecting defence and arms control issues, not be inadvertently extended by Article 208 .

The literal result would produce an anomaly that sound interpretation should seek to avoid. There are at least three ways to ensure that these basic environmental obligations are respected in waters landward of the EEZ. One is to regard oil platforms, rigs, and other installations used in connection with the exploration of the sea-bed and the exploitation of its resources as being sea-bed activities coming within the rights of the coastal state over the sea-bed by virtue of its sovereignty, independently of its rights over installations and structures. ${ }^{9}$ This would render the cross-reference to Articles 60 and 80 largely irrelevant in waters landward of the EEZ. Another would be to recognize that there is no geographic gap in the application of the general environmental obligations set forth in Articles 192 and 194, and that the best place to look in deciding how to apply these obligations to installations landward of the EEZ is Article 208. Yet another would treat the cross reference as relevant only to installations seaward of the territorial sea, and not as limiting the application of Article 208 obligations to installations in principle.

A potentially more important question concerns the relevance of the rules set forth in Article 60 to straits and archipelagic waters. Article 60, which appears in Part V of the Convention on the EEZ, ${ }^{10}$ is one of three similar sets of provisions that deal with offshore installations. Of the other two, those in Part XIII dealing

Article 208(5).

Article 208(3).

Article 208, paras. 1-3.

Ibid.

This approach is consistent historically with the 1958 Convention on the Continental Shelf, which contained no separate allocation of jurisdiction over offshore oil and gas platforms, but rather treated such jurisdiction as implicit in the sovereign rights of the coastal state over exploration and exploitation of the resources of the continental shelf.

10

It is incorporated by reference in Article 80 with respect to the continental shelf. 
with scientific research installations apply to all of the marine environment, including straits and archipelagic waters. ${ }^{11}$ On the other hand, Article 147 concerns only installations used for exploration and exploitation of resources in the international sea-bed area.

There are three possibilities regarding the relevance of the rules set forth in Article 60:

1. they are applicable to straits and archipelagic waters;

2. they are inapplicable to straits and archipelagic waters;

3. they are inapplicable to straits and archipelagic waters, but inform the meaning of other provisions that are applicable to such waters that prohibit hampering, impeding, suspending or obstructing passage.

In my view, all three possibilities apply to Article 60, depending on the particular provision of that article.

The rules in paragraphs 1 and 2 should be placed in the inapplicable and irrelevant category. Those rules are designed to establish coastal state jurisdiction over offshore installations, and are both textually inapplicable to, and logically unnecessary in, waters subject to the sovereignty of the coastal state, including those in straits and archipelagic waters.

On the other hand, the rule in paragraph 8 of Article 60 - that artificial islands and offshore installations and structures do not possess the status of islands, have no territorial sea of their own, and do not affect the delimitation of the territorial sea, the EEZ or the continental shelf - contains no express geographic limitation and is both textually and logically applicable to all of the sea, including straits and archipelagic waters.

What remains are the rules contained in paragraphs 3 to 7 of Article 60. These rules deal with the important questions of accommodation of uses, interference with navigation and safety of navigation in connection with offshore installations. Logically these provisions are relevant to all waters subject to coastal state jurisdiction in which other states enjoy navigation rights. This is particularly true in straits and archipelagic sea lanes where, because of their importance to navigation, the Convention accords all states particularly liberal passage rights. But as a textual matter, except for paragraph 7 , these provisions expressly apply only to the EEZ and the continental shelf.

Article 60 , paragraph 7 provides that offshore installations and the safety zones around them "may not be established where interference may be caused to the use of recognized sea lanes essential to international navigation." 12 It contains no express geographic limitation on its application, and is both textually and logically applicable to straits and archipelagic waters either directly or as a 
guide to interpreting the prohibitions on hampering, impeding, suspending or obstructing passage.

The reference to sea lanes in paragraph 7 is not necessarily synonymous with sea lanes approved by IMO and designated by the riparian state in straits and archipelagic waters. Nevertheless, IMO approval would be strong evidence that a sea lane is recognized. And the fact that the regime of transit passage or archipelagic sea lanes passage applies is itself strong evidence of the importance of the route to international navigation.

This does not necessarily mean that no installations or safety zones may be established in IMO approved sea lanes. What paragraph 7 prohibits is possible interference. Whether interference may be caused depends on the circumstances. Where traffic is heavy or passages are narrow-the classic situations in which IMO considers sea lanes and traffic separation schemes, and a frequent situation in straits-it may be difficult to argue that no interference may be caused. The same is not necessarily as true in open areas in which archipelagic sea lanes may be up to 50 miles wide.

The rules in paragraphs 3 to 6 of Article 60, among other things, incorporate international standards regarding the safety of navigation in the vicinity of offshore installations, the breadth of safety zones around installations, and the removal of installations. These paragraphs, unlike paragraph 7 , are explicitly applicable only to the EEZ and the continental shelf. But these paragraphs, as well as paragraph 7, may, and generally should, inform more precisely the meaning of provisions of the Convention expressly applicable to straits and archipelagic waters that prohibit hampering, ${ }^{13}$ impeding, ${ }^{14}$ suspending ${ }^{15}$ or obstructing ${ }^{16}$ passage. This would provide helpful guidance to both riparian states and maritime users regarding the criteria for dealing with this matter.

\section{Navigation}

With respect to straits and archipelagic waters, three navigation regimes apply under the Convention.

"Transit passage" applies to "straits which are used for international navigation between one part of the high seas or an exclusive economic zone and another part of the high seas or an exclusive economic zone", subject to certain exceptions. ${ }^{17}$ Transit passage is defined as "the freedom of navigation and overflight solely for the purpose of continuous and expeditious transit of the strait." 18

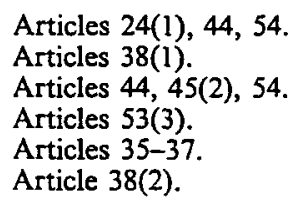


"Archipelagic sea lanes passage" applies to sea lanes and air routes thereabove suitable for the continuous and expeditious passage of foreign ships and aircraft through and over archipelagic waters and the adjacent territorial sea, designated by the archipelagic state after adoption by IMO. ${ }^{19}$ In the absence of such designation in accordance with the Convention's requirements, archipelagic sea lanes passage applies through the routes normally used for international navigation. ${ }^{20}$ Archipelagic sea lanes passage is defined as the exercise "of the rights of navigation and overflight in the normal mode solely for the purpose of continuous, expeditious and unobstructed transit". ${ }^{21}$

"Innocent passage" applies in those parts of archipelagic waters and the adjacent territorial sea to which the more liberal right of archipelagic sea lanes passage does not apply, and in the territorial sea (and internal waters formed by straight baselines) in straits to which transit passage or a long-standing special conventional regime does not apply. ${ }^{22}$ The Convention contains a detailed definition of innocent passage. ${ }^{23}$

As one might expect, the Convention places great emphasis on all three roles of IMO with respect to navigation in general, and these navigation regimes in particular.

\section{Forum Role}

Article 211, paragraph 1, clearly engages IMO's forum role. It requires states to establish international rules and standards to control pollution from ships, and to promote the adoption of routeing systems designed to minimize the threat of accidents which might cause pollution. This is to be done through the competent international organization or general diplomatic conference. IMO meets these requirements both directly and as the organization that convenes and assists relevant diplomatic conferences.

Because the Convention contains no general chapter on navigation safety comparable to its chapter on protection and preservation of the marine environment, it contains no comparable general reference to IMO as a relevant forum for developing standards with respect to navigation safety, apart from routeing systems. However, Article 194, paragraph 3(b) makes clear that measures to control pollution from vessels include measures for preventing accidents and ensuring the safety of operations at sea. In addition, the navigation safety provisions of the Convention themselves assume the existence of international navigation safety regulations. One may conclude that IMO's traditional role as the forum for such international regulatory activity was thus assumed.

Article 53.

Article 53(12).

Article 53(3).

Articles $8(2), 35,45(1), 52$. Innocent passage may not be suspended in straits used for international navigation. Article $45(2)$.

Articles 18-19. 


\section{Standard Setting Role: Flag State Duties}

IMO's standard setting role is a key to the Convention's provisions on navigation. The Convention effectively converts IMO from a forum for negotiation into an organ whose work product, if generally accepted, will have legislative effect on all states, ${ }^{24}$ even those states that are not IMO members or parties to the treaty containing the relevant standards.

Flag states are required to adopt pollution control laws and regulations for their ships that "at least have the same effect as that of generally accepted international rules and standards established through the competent international organization or general diplomatic conference. $" 25$ This duty is enforceable under the compulsory dispute settlement provisions of the Convention, which include the right to seek binding provisional measures either "to protect the respective rights of the parties to the dispute" or, in an interesting innovation, "to prevent serious harm to the marine environment". ${ }^{26}$

With respect to a very wide range of specified navigation safety standards emanating from the work of IMO, Article 94 of the Convention provides that the flag state "is required to conform to generally accepted international regulations, procedures and practices," and to "secure their observance."27 Article 94 applies as such only to the EEZ and the high seas beyond. ${ }^{28}$ The very nature of its provisions, however, is such that the violations generally would be continuing ones and the geographic limitation would rarely, if ever, make a practical difference. ${ }^{29}$ Should there be a violation in straits or archipelagic waters, the riparian states would have standing to demand compliance in their capacity either as coastal states in the EEZ or as maritime users of the EEZ and the high seas, or they might use Article 94 to inform the meaning of more generally worded provisions of the Convention that establish a duty for ships in passage through their waters to comply with relevant international navigation safety standards. In this connection, ships in innocent passage must comply with all generally accepted international regulations relating to the prevention of

At least all states party to the LOS Convention depending on one's view of customary international law on this point.

Article 211(2). The author analysed the meaning of the words "generally accepted" in B.H. Oxman, "The Duty to Respect Generally Accepted International Standards" (1991) $24 \mathrm{New}$ York Univ. J. Int'l L. \& Pol. 109.

Articles 286, 290, 297(1)(b).

Article $94(5)$.

Articles 58(2), 86.

In this connection, one might recall that Ambassador Arias-Schreiber of Peru once suggested at the Law of the Sea Conference that general provisions regulating ships, such as those found in Article 94, might be reassembled in a new general chapter of the Convention, rather than appearing in the chapter on the high seas. The logic of his suggestion is intriguing, but the work required to effect the reorganization could have reopened sensitive issues that other delegations preferred to treat as settled. 
collisions at sea. ${ }^{30}$ Ships in transit passage or archipelagic sea lanes passage must "comply with generally accepted international regulations, procedures and practices for safety at sea, including the International Regulations for Preventing Collisions at Sea." 31

\section{Standard-Setting Role: Coastal State Regulatory Powers}

One of the most important aspects of the Convention is the manner in which it deals with coastal state regulatory and enforcement powers over foreign ships exercising navigational rights and freedoms. There is an inevitable tension between a right or freedom of one state to navigate, arid a power of another state to regulate, and thus restrict, that right or freedom. The challenge is to establish a system that minimizes this problem.

Flag state duties to respect international standards are an important part of the answer. Subjecting those flag state duties to compulsory third-party dispute settlement is another important part of the answer. But this was not regarded as sufficient. For practical, conceptual and historical reasons, coastal states were also accorded some regulatory powers over ships navigating in waters subject to their sovereignty, and some powers to enforce their own as well as international regulations.

\section{Innocent passage}

Coastal state regulatory powers with respect to navigation safety and prevention of pollution are most extensive with respect to innocent passage. ${ }^{32}$ But these powers are not unlimited. Coastal state regulations with respect to the construction, manning, equipment, or design of foreign ships are permitted only to give effect to generally accepted international rules or standards. ${ }^{33}$ Moreover, the duty of the coastal state not to hamper innocent passage, ${ }^{34}$ as well as the duty of foreign ships in innocent passage to comply with generally accepted international regulations relating to the prevention of collisions at $\mathrm{sea}^{35}$ and the duty of the flag state to provide for the effective enforcement of international rules and standards for the prevention of pollution "irrespective of where a violation occurs" 36 imply some substantive limitations on the regulatory discretion of the coastal state to impose requirements incompatible with these duties.

The coastal state has the power to prescribe sea lanes and traffic separation noxious substances must, while in innocent passage, carry documents and observe special precautionary measures established for such ships by international agreements. Article 23 . Articles 39(2)(a), 54

Articles 21(1)(a) and (g), 22.

3 Article 21(2).

Article 24.

35 Article 21(4).

Articles 211(2), 217(1) 
schemes for ships in innocent passage. ${ }^{37}$ But it must take into account the recommendations of the competent international organization, that is IMO. ${ }^{38}$ This requirement may relate both to general IMO recommendations regarding all sea lanes and traffic separation schemes, and to specific IMO recommendations regarding the particular sea lanes and traffic separation schemes being considered by the coastal state. While the obligation is only to take into account the recommendations, the coastal state risks violating its obligation not to hamper innocent passage ${ }^{39}$ if it ignores IMO recommendations, and conversely is on strong ground if it implements them.

\section{Transit passage and archipelagic sea lanes passage}

The regimes of transit passage and archipelagic seas lanes passage generally apply in areas where there is no equally convenient alternative route, or in some cases no alternative at all. As a result, interference with navigation in those areas is a more sensitive problem, and the regulatory and enforcement powers of the riparian states over navigation are therefore carefully limited. In contrast to the innocent passage regime, states bordering straits and archipelagic states have no unilateral regulatory power to impose sea lanes, traffic separation schemes, or other safety or pollution measures on ships in transit passage or archipelagic sea lanes passage.

With respect to "the safety of navigation and the regulation of marine traffic" the regulatory powers of the riparian states are limited under Article 42(1)(a) to measures for which they receive approval from the competent international organization "as provided in Article 41."40 Under Article 41, the riparian state proposes measures to IMO, which may only approve measures agreed by the riparian state. The measures may be implemented by the riparian state only after IMO approval.

This being said, it is equally important to emphasize that Article 41 itself, while referring explicitly only to sea lanes and traffic separation schemes, should be read liberally so as to permit full implementation under Article 41 of the full substantive scope of the regulatory powers under Article 42(1)(a) that are to be implemented "as provided in Article 41", namely the adoption of any measures consistent with the Convention deemed necessary by the riparian state and IMO for the safety of navigation and the regulation of marine traffic. This liberal reading of Article 41 advances coastal, maritime, and environmental interests,

Article 42 applies mutatis mutandis to archipelagic sea lanes passage under Article 54. For purposes of the cross reference to Article 41, it makes no difference in substance that the relevant IMO approval requirement is set out separately for archipelagic sea lanes in Article 53. The same result would obtain if the cross-reference were read to mean Article 53 for purposes of archipelagic sea lanes passage. 
any or all of which could be prejudiced in practice and in principle were a serious regulatory vacuum to emerge.

A reasonable case can be made that the cross-reference to Article 41 in Article $42(1)(a)$ is in fact procedural and that this makes it unnecessary for the riparian state and IMO to attach other safety and traffic regulations to sea lanes or traffic separation schemes in order to act under Article 42(1)(a). But I am prepared to concede that fig leaf to those who demand interpretive modesty. This is exactly what was done in the Straits of Malacca and Singapore, where underkeel clearance requirements-strangers at the time to conventional notions of traffic regulation-were attached to a traffic separation scheme in IMO as part of arrangements leading to support for the straits and archipelago provisions of the draft LOS Convention by Indonesia, Malaysia and Singapore, on the understanding that the underkeel clearance requirements would be enforceable under the Convention pursuant to Articles 41, 42(1)(a) and 233.

With respect to pollution from ships, the regulatory powers of the riparian states with respect to transit passage and archipelagic sea lanes passage are limited to "giving effect to applicable international regulations regarding the discharge of oil, oily wastes and other noxious substances."41 I believe the discharge standards that are "applicable" to foreign ships in transit passage and archipelagic sea lanes passage under the Convention are those identified in the straits chapter itself, namely in Article 39(2)(b), which requires ships in transit passage to comply with "generally accepted international regulations, procedures and practices for the prevention, reduction and control of pollution from ships." 42 Apart from its textual clarity and administrative coherence, ${ }^{43}$ this result also has the merit of being consistent with the regulatory power of the coastal state in the EEZ seaward of the territorial sea through which ships in transit passage and archipelagic sea lanes passage normally must navigate. ${ }^{44}$

Consideration of the Indonesian archipelago, which itself borders the Straits of Malacca and Singapore, invites additional candour about some relevant negotiating history. The real issue concerns the enforcement powers of straits

41

42 Article 39 applies mutatis mutandis to archipelagic sea lanes passage under Article 54.

43 The negative implication, if any, created by the failure of the Conference at its closing session to adopt a formal Spanish amendment changing the word "applicable" to "generally accepted" is in my view insufficient to overcome a literal, coherent, and logical interpretation of the text of the Convention itself. The reality is that a Conference that eschewed voting throughout its decade of work was reluctant to risk unravelling complicated "package deals" by adopting formal amendments by vote at its conclusion. The same caution was evident for several years in the work of the Conference Drafting Committee, which declined to consider any change in the text of the draft Convention if any delegation declared that it regarded the change as substantive. "Coastal states, for the purpose of enforcement as provided for in section 6, may in respect of their exclusive economic zones adopt laws and regulations for the prevention, reduction and control of pollution from vessels conforming to and giving effect to generally accepted international rules and standards established through the competent international organization or general diplomatic conference." Article 211(5). 
states and archipelagic states with respect to ships in transit passage and archipelagic sea lanes passage. The relevant text is the second sentence of Article 233, which permits straits states explicitly, and archipelagic states implicitly, ${ }^{45}$ to take enforcement measures if a violation of laws and regulations referred to in Article 42, paragraph 1(a) and (b), causes or threatens major damage to the marine environment. The text of that sentence was added by the Third Committee of the Law of the Sea Conference to Part XII on pollution after the straits articles were essentially in their final form as found in Part III, in part to avoid possible opposition from states that might fear reopening the text of the straits articles as such in the Second Committee of the Conference.

The text of the sentence was worked out on the basis of a proposal agreed by representatives of the United States and senior Malaysian officials in Kuala Lumpur. After agreement was reached there, the US representatives travelled immediately to Singapore and Jakarta to confirm that the governments concerned were prepared to join Malaysia in accepting the draft straits articles before the Conference with the addition of this sentence to the pollution text, the adoption by IMO of underkeel clearance requirements for the Straits of Malacca and Singapore, and the understanding that these underkeel clearance requirements would themselves become enforceable by the states bordering those Straits under the Law of the Sea Convention in accordance with the provisions that became Articles 41, 42(1)(a) and 233 of the Convention.

The final meeting in Jakarta had been preceded by several years of diplomatic talks by senior officials, and high level Navy-to-Navy talks, between Indonesia and the United States regarding the proposed texts, meaning and application of the provisions that finally emerged in the Convention with respect to archipelagic waters, archipelagic sea lanes, and archipelagic sea lanes passage with the support of Indonesia, the United States, and other interested states with which they consulted closely. Accordingly, this final round of talks in Jakarta on the texts before the Conference regarding straits and archipelagic waters was concluded quickly enough to permit the US representatives to squeeze in a day of rest in Bali before resuming their planned itinerary.

These negotiations removed the final obstacles to the emergence of general support at the Conference for the provisions on straits and archipelagic waters and sea lanes. I cannot of course speak for my American, Indonesian, Malaysian or Singaporean colleagues in these talks, but it never occurred to me that the enforcement powers we added to Article 233 were not over discharges in violation of what became Article 39 of the Convention by all ships not entitled to sovereign immunity, but only, as some now suggest, over discharges by ships that violate standards accepted by their flag State in another instrument.

45 The second sentence of Article 233 permits enforcement of law: and regulations referred to in Article 42(1)(a) and (b), which is itself applicable to archipelagic sea lanes passage by virtue of its incorporation by reference in Article 54 . 


\section{Approval Role}

Articles 41 and 53 accord the competent international organization, that is IMO, an approval role with respect to all sea lanes and traffic separation schemes, and other measures regarding navigation safety and traffic regulation, with respect to transit passage of straits and archipelagic sea lanes passage. IMO may adopt only those sea lanes, traffic separation schemes, and other measures to which the states bordering a strait or the archipelagic state agree. Similarly, the states bordering straits and the archipelagic state may only designate sea lanes and prescribe traffic separation schemes and other measures after approval by IMO. ${ }^{46}$ If they are approved by IMO and promulgated by the riparian states in accordance with Articles 41 or 53, then all ships in transit passage or archipelagic sea lanes passage must respect them. ${ }^{47}$

What we have here, in effect, is co-operative legislative competence of an unusual kind. The competence is exercised by a state, but the state may act only with the approval of an international organization.

Particularly in light of the fact that sea lanes, traffic separation schemes and other measures are subject to compulsory dispute settlement under the Convention, and that detailed substantive standards are not specified at least with respect to straits, it is reasonably clear that IMO is expected to make an independent judgement based on its experience and technical expertise.

In this regard, one might consider the difference between sea lanes in straits and in archipelagic waters. In straits, the purpose of sea lanes is the classic one: Article 41 specifies that they may be established "where necessary to promote the safe passage of ships".

In archipelagic waters, although the promotion of safe passage of ships remains important, another purpose of sea lanes is to clarify where the right of archipelagic sea lanes passage applies. Archipelagic sea lanes may extend through significant areas of open sea, may be up to 50 nautical miles wide, and must include all normal passage routes used as routes for international navigation or overflight and, within such routes, all normal navigational channels. ${ }^{48}$ At the same time, duplication of routes of similar convenience

46 Article 41(4), 53(9). See pp. 476-477 above for discussion of other measures regarding navigation safety and traffic regulation.

47 Articles 41(7), 53(11).

48 Article 53(4). Questions have been raised in this connection with respect to fishing vessels because of concerns regarding illegal fishing. While fishing vessels enjoy the same right of archipelagic sea lanes passage as other ships, this right exists "solely for the purpose of continuous, expeditious and unobstructed transit" through the archipelago. Co-operative arrangements between the archipelagic state and flag states or vessel owners might be appropriate in some circumstances for purposes of ensuring that such transit is in fact the sole purpose for the presence of fishing vessels in archipelagic waters in which they are not authorized to fish. In addition, the archipelagic state, while duty bound to respect passage rights, is generally free to deny fishing rights or other privileges it voluntarily accords to a state that is not taking appropriate steps to prevent its vessels from fishing illegally. 
between the same entry and exit points is not necessary. These provisions were designed to accommodate not only the needs of merchant shipping but the normal dispersal of ships and aircraft in a naval task force and normal defensive mancuvring for naval vessels. ${ }^{49}$

Perhaps the most remarkable feature of Articles 41 and 53 is that there is no mention of the procedures for approval. ${ }^{50}$ This is particularly striking because of the magnitude of existing military, economic and other interests affected by navigation in straits and archipelagic waters. It is obviously an extraordinary tribute to the procedures, practices and reputation acquired by IMO over the years that neither riparian nor maritime interests deemed it necessary to obtain express procedural protections in the Convention regarding the approval process.

IMO has more direct and immediate control over navigation in exercising its approval role under Articles 41 and 53 of the Law of the Sea Convention than it has under any other instrument. Once IMO gives its approval and the riparian state acts, all ships must comply under the LOS Convention. There is no opting out.

Now that the Convention is in force, IMO would be well advised to clarify the procedures relevant to the exercise of its approval role, bearing in mind the principles of widespread and representative support and accommodation of the interests of specially affected states that informed the consensus system used at the LOS Conference itself with respect to these issues. A practical approach consistent with the expectations of states in reposing their trust in IMO would be to look for guidance in the rules and practices of IMO and its Maritime Safety Committee in dealing with routeing systems.

A discussion of IMO's approval role would not be complete without some mention of Article 211, paragraph 6, which requires the concurrence of the competent international organization for the designation by the coastal state of a particular area in which more stringent international pollution standards applicable to special areas apply, or in which more stringent coastal state standards regarding discharges and navigation practices may apply if the organization agrees. This paragraph applies only to the EEZ. The main reason is doubtless that, with respect to innocent passage in the territorial sea and elsewhere, the coastal state has unilateral regulatory powers with respect to discharges from ships. ${ }^{51}$ Moreover, pursuant to Article 233 , nothing in the

49 Since air routes must be above the archipelagic sea lanes under Article 53(1), in theory yet another factor not traditionaliy considered in connection with sea lanes is relevant. In practice, this is unlikely to pose any difficult technical problems. Civil aircraft are required by Article 39(3)(a) and Article 54 to observe the ICAO Rules of the Air in any event, and the main practical import of the air routes is likely to concern state aircraft which are not subject to ICAO regulation as such.

50 This might be contrasted with the years of negotiation at the LOS Conference and thereafter on the question of voting procedures in the International Sea-Bed Authority.

51 Article 21(1)(f). 
section in which Article 211 appears "affects the legal regime of straits used for international navigation". This is because the transit passage and archipelagic sea lanes passage regimes contain their own rules regarding pollution from ships.

Thus, with respect to transit passage and archipelagic sea lanes passage, no express provision is made for imposition of special discharge standards. ${ }^{52}$ However, since the general international pollution standards for ships close to shore are very stringent in any event, and are becoming stricter all the time, this may not be much of a practical problem. Should special discharge standards be needed for a particular area in which transit passage or archipelagic sea lanes passage applies, the most obvious solutions are for the states concerned to propose that relevant flag states adopt them for their ships or that IMO adopt them and try to assure that they can be regarded as generally accepted under Article 39(3)(b) as quickly as possible. It should also be borne in mind that direct enforcement of regulatory measures is not the only way to deter pollution. Nothing in the LOS Convention affects the institution of civil proceedings in respect of any claim for loss or damage resulting from pollution of the marine environment. $^{53}$

\section{Conclusion}

IMO has been made a partner in the regulation of navigation and prevention of pollution in straits and archipelagic waters. In performing this role, it must look out for the interests of all states in safe, efficient, and environmentally sound use of such waters. The results of its regulatory work, at least when generally accepted, have been made legally binding under the Law of the Sea Convention without regard to whether a state is otherwise bound by such results. IMO is also given a new approval role as part of a new and innovative experiment in cooperative legislative competence. IMO's work, at least at present, is more central to the realization of the object and purpose of the Law of the Sea Convention than that of perhaps any other international organization.

These are very sobering and exciting thoughts. Only time will tell if IMO is equal to the task. For my part, I have every confidence that it can be.

52 Given the general absence of equally convenient alternative routes in areas in which such passage rights exist, and concerns about the impact of Convention texts on the unilateral practice of nonparties, this may have been deliberate.

Article 229. 